\title{
HRISTO KYUCHUKOV
}

\section{Adult literacy in the Roma community: two case studies}

Streszczenie: $\mathrm{W}$ artykule zaprezentowano wyniki dwóch projektów z udziałem dorosłych Romów z Bułgarii i Szwecji. Romowie posiadali umiejętność czytania i pisania w ich języku ojczystym - romskim, a w procesie alfabetyzacji użyto podejścia ekologicznego. Proces ten zakłada, że tło kulturowe i kulturowe środowiska uczących się powinny zostać użyte jako główne narzędzie w procesie alfabetyzacji. Rezultatem obu projektów było nie tylko osiągnięcie przez biorących w nich udział Romów umiejętności piśmienniczych w języku romskim, ale także zdobycie wiedzy na temat ich historii i kwestii tożsamościowych.

Wyrazy kluczowe: Romowie, dorośli, alfabetyzacja, podejście ekologiczne

\section{Introduction}

All Roma communities around the world are multilingual. Acquiring the languages of other minorities which are in contact with them and acquiring the languages of the mainstream society is a natural phenomenon for them. Moreover, the Roma usually speak several other Romani dialects in order to communicate with other Roma groups. However, Roma communities are illiterate in their mother tongue. They can communicate easily in several Romani dialects, but they cannot read and write in Romani. At the same time they can read and write in several other international languages as English, French, Spanish, German and Russian.

Although Romani is not a standardized language, it is a language with its own features. It comprises many dialects and all dialects of Romani derive from the common ancestor - a language once spoken in India. All dialects share the same core of non-European words and the same grammatical system. One can also find words in Romani from Iranian, Armenian and Greek. This is a result of the migration route of Roma from India into Europe. Nevertheless, all Roma in Europe speak dialects which are comprehensive for each other, except the Roma in Finland, Spain, England and the German Sinti 
were the influences of the majority languages on Romani dialects are very large (Matras, 2002; Kyuchukov, 2003)

The goal of the paper is to show how different Roma communities, speakers of different Romani dialects, get literate in Romani, using their cultural characteristics and not changing their environment. According to the ecological approach (Nichols, 2015), the environment is not changed where the Roma people live. The everyday live in the Roma community can be observed and all the activities which they do can be used for the process of literacy. I would like to show different approaches to the literacy process within Roma communities with no change in their natural environment. It can be expected that having basic knowledge in their mother tongue and knowing how to read and write it will preserve their identity and will develop the whole community.

\section{Roma communities in two European countries}

\section{Bulgaria}

The Roma in Bulgaria are spread all over the country and usually they live in ghetto like settlements outside the towns and cities. For the purpose of this study, the situation in the Roma settlement in the town of Vidin - located in North West, will be presented.

The total number of Roma living in the Roma settlement is approximately 15 000. There are two groups of Roma living in the settlement - so called Muslim Roma and Christian Roma. The Muslim Roma used to be also a Turkish speaking community, howeve, $r$ the younger generations nowadays speak only Romani and Bulgarian. The older generation still knows some Turkish. The Christian Roma are Romani and Bulgarian speakers. In the community, the groups are often closed for inter-group communication. Although they live in the same settlement, they do not have many contacts with each other. The division of the groups is based also on the professions which different groups used to practice in the past - blacksmiths, basket makers, flower sellers, horse dealers. Nowadays, the young generations do not practice these professions anymore.

The religion of the Roma in the town is represented mainly by Muslims and Orthodox Christians. However, nowadays one can find a strong Pentecostal movements among the Roma. Some of the Muslims and Christians turn to Pentecostals and their masses are in Bulgarian or in Romani. 
The Romani settlement is a small town within the town. Although it is placed in the surroundings of the town, the life here is well developed. During the communist regime, the government built a school and a hospital to meet the community needs. In the settlement, there is an open mini-market, where people sell vegetables, fruit, fish and meat.

The "cultural" life usually takes place on the street. During the summer, people sit on the street and tell stories to each other, youngsters play music or dance. The wedding celebrations usually are in an open air on the street and the whole community joins them.

In the settlement, there is a segregated school and kindergarten. Most frequently, the Roma families send their children to school and most of the members of the community are educated - at least they know to read and to write in the Bulgarian language. In the community, there are also intellectuals who are teachers or nurses. Most of the families have access to the radio, television, and internet. Lately, there have been also young Roma people studying at universities.

An important fact in the life of the community is the development of new Roma non-government organizations (NGO). The Roma women movement has become active over the recent years and they organize themselves in women organizations.

In general the community keeps Roma traditions and Romani lifestyle, although the younger generation is not much interested in it anymore. There are few things very typical of the community, which do not depend on their religion and the divisions inside groups. The first important thing for Roma are family bonds. Many Roma families live together, because of their traditions. For Roma communities. the family life plays an important role. Living closely, families help each other and support each other in many ways.

\section{Sweden}

According to the official sources, the total number of Roma in Sweden is approximately 40000 , but in fact these statistics cannot be trusted because there are many Roma who travel throughout the year between Finland and Sweden or between Sweden and other European countries, like France, Spain and Poland. The Roma are mostly concentrated in the big towns and cities, and it is commonly believed that their number is at least 100 000. Recently, there have also been Roma form Bulgaria, Romania, Serbia and Macedonia immigrating to Sweden. 
The Roma in Stockholm are spread all over the city - however, in one of the city parts called "Rinkiby" their number is much higher. There are aboit 3000 Roma who live in Stockholm. They are devided into two main groups: Finish Roma and European Roma, and the communication between these two groups is rather poor. The Roma community have their own cultural center, the children receive instructions in their mother tongue in kindergartens and in schools.

As it was mentioned above, the Finnish Roma community speaks a dialect called "Finnish Romani", which in a way is different from the dialects of the other Roma who immigrated to Sweden from France, Spain, Poland, Serbia, Macedonia and Bulgaria. Nowadays many Finish Roma learn the Romani dialects spoken by some other Roma groups, because one of the criteria for the Romani identity, in their opinion, is the language. There is a strong feeling to the language in the community. The younger generation keeps the language and children get instructions in Romani in kindergarten and in primary school. For all Roma communities, the language plays an important role for the Romipen - the Roma identity.

The Roma in Sweden are very strong in keeping the old traditions. There is a very sharp division between men and women in the community. During the community parties, women are usually separated from men. There is a strong distance between young and old generations as well. The young do not have the right to speak freely or to behave improperly in front of adults.

The religion of Roma community in Sweden is mainly Pentecostal. There is also a small number of Roma who are Catholics and Orthodox, among those who have immigrated to Sweden from other European countries. However, the Pentecostal movement among Roma is very strong. There are Roma churches and the New Testament is translated into Romani.

The Roma communities in both countries do not differ much from each other. The differences mostly concern the living conditions. Generally speaking, the rest (language, culture and traditions) does not differ much. In both countries, the Roma form a group of minority which, very often, does not have the same cultural or human rights as the other existing minorities in the country. One of the reasons of so many European Roma being illiterate in their mother tongue is the educational system and the government, which until very recently did not recognize Roma as a minority with equal educational rights. 


\section{The theoretical background of adult literacy in the community}

The main approach used for literacy in the community in this study is within the framework of the ethnography of communication as conceptualized by Hymes (1974) and Bauman (1975). Within this framework, speaking (as well as reading and writing) are viewed as ways of communication that are characteristic of a particular cultural group. In the past, literacy has been a subject of both theoretical debate and empirical research. Much of this activity was stimulated by Goody and Watt's (1963) suggestion that the development of literacy within societies brings changes in cognition - in the way people think. Yet, cognition in cultures with literacy does not differ fundamentally from cognition in illiterate cultures (and Goody and Watt's initial hypothesis might be absolutely wrong) and while there may be some differences, particularly over the long run of history, between literate and illiterate societies, this does not mean that literacy is superior to orality.

It is important to note that Goody modified his original standpoint on this issue in later publications. Goody perceives literacy as having influence on changes in thinking within the history of Western civilization, but he no longer treats it as a single cause (Goody, 1986, 1987). Literacy and some factors may indeed stimulate some changes - both cognitive and cultural over the centuries, but the ability to think abstractly or to be "civilized" are not the exclusive field of "literate thinking". There is limited support for the hypothesis that literacy may enable a kind of "linear" thinking, and perhaps other specific kinds as well, especially in relation to how literacy is used in a given culture (Scribner and Cole, 1981).

\section{The study}

The study was conducted in two Roma communities: two different projects for adult Roma literacy in two different parts of Europe - Bulgaria and Sweden, where the same approach for building literacy skills was used - the ecological approach to literacy within the community. The goal of this study is to share ideas and approaches used for literacy among Roma communities in Bulgaria and Sweden. The reason for literacy in the Romani language in those two communities were different. Among the Bulgarian Roma the literacy process was a part of a larger project on early child home literacy in 
which parents played the role of teachers at home. The role of parents was to train their children who are aged 3-5 and do not attend kindergarten to read and write in the Bulgarian language using the mother tongue instructions as a bridge for better understanding and acquisition of Bulgarian. For this purpose, special courses for parents were organized. During these courses, parents were trained in two directions: 1 ) how to read and write in Romani and 2) how to teach their children in Bulgarian as a second language using Romani language as an instrument.

The literacy project among the Finnish Roma community in Stockholm was a natural wish of the group of Roma to improve their Romani and to learn to read and write in the Romani language. For this purpose a literacy course was organized with Roma adults.

The ecological approach, used for literacy, suggested the Romani cultural heritage to be used as an instrument for language literacy - songs, fairy tales and poems.

\section{The results}

During the literacy process, the students were learning Roma songs, fairy tales, and the Roma history. Through learning to read and write texts of songs and fairy tales, which are culturally close to them, the participants actually got literate in their mother tongue.

The results of the Bulgarian project were of two types: firstly, the parents learned to read and write in Romani, and secondly, the children got prepared for school.

The result of the Swedish project was that at the end of the year the participants of the literacy course could read and write in Romani.

In both projects the adults were aware of the importance of their own culture in the literacy process and, for them, that was the first time they had realized that culture plays an important role in the educational process.

What were the difficulties for both groups of adults learning to read and write in Romani as their mother tongue?

1. The first difficulty came from the introduction of the new Roma alphabet. The Bulgarian Roma are used to reading and writing in the Cyrillic alphabet. The Finnish Roma are literate in Swedish and/or Finnish. Thus, the Romani alphabet with some specific letters (such as $k h, p h$, čh, $t h$, č, š) and their correct pronunciation caused problems, particularly for the Finnish Roma. 
2. The vocabulary: in both groups the participants have forgotten some of the old Romani words and instead they use words that come from contact languages. Learning the meaning of the words and using them in communication is another difficulty for the learners of Romani.

3. The communication: problems with starting the communication in Romani, using the new vocabulary, etiquette forms and correct behavior.

\section{Conclusions}

According to Freire and Macedo (1987), literacy and education are interconnected with the culture. "To be literate is not to be free, it is to be present and active in struggle for reclaiming one's voice, history, and future" (p. 11). In the further part, the authors develop the idea that the language is not only the force of knowledge, but also knowledge itself. The idea of critical literacy, which the authors develop, is to make the learners rethink themselves, their position in the educational process, in the society and life.

In fact, the Roma involved in these two projects were totally changed at the end of them. This is not only due to the literacy process itself but also owing to education, learning their own history and culture, finding new facts about their past, making them more proud of who and what they are.

\section{Bibliography}

Hymes, D. 1974. Foundations in Sociolinguistics: An Ethnographic Approach. Philadelphia: University of Pennsylvania Press.

Bauman, R. 1975. Verbal Art as Performance 1. American Anthropologist. 77 (2).

Freire, P. and Macedo, D. 1987. Literacy. Reading the word and the world. Westport: Bergin \& Garvey.

Goody, J. and Watt, I. 1963. The Consequences of Literacy. Comparative Studies in Society and History. 5 (3), pp. 304-345.

Goody, J. 1987. The Interface Between the Written and the Oral. Cambridge: Cambridge University Press.

Goody, J. 1986. The Logic of Writing and the Organization of Society. Cambridge: Cambridge University Press.

Kyuchukov, H. 2003. Kratko opisanie na romskiya ezikv Bulgaria. Sofia: Delfi. 
Matras, Y. 2002. Romani: A linguistic introduction. Cambridge: CUP.

Nichols, S. 2015. Ecological approaches to literacy research. In: Rowsell, J. and Pahl, K. eds. Routledge Handbook of Literacy Studies. Oxford: Routledge, pp. 104-123.

Scribner, S. and Cole, M. 1981. Psychology of literacy. Cambridge: Mass. Harvard University Press.

\section{Adult literacy in the Roma community: two case studies}

Abstract: The paper presents the results of two literacy projects with Roma adults form Bulgaria and Sweden. The Roma were literate in their mother tongue - the Romani language and the ecological approach to the literacy process was used. The approach assumes that the cultural background and cultural environments of learners should be used as a main tool in the literacy process. The results of the two projects were not only that adult Roma had acquired literacy skills in Romani, but also that they had got the knowledge of their history and identity issues.

Keywords: Roma, adults, literacy, ecological approach

Translated by Hristo Kyuchukov 